\title{
Indecencia, mortificación y modos de ver en la pintura del Siglo de Oro
}

\author{
JaVIER Portús PÉREZ
}

Una estampa grabada probablemente por Francisco Navarro hacia 1639 y destinada a ilustrar una historia de la vida de San Juan de Dios nos enseña el interior de una habitación de la que destacan una cama cerrada por unos cortinajes y varios cuadros que cuelgan de las paredes. En primer término, a la izquierda, aparecen cuatro mujeres lujosamente vestidas y sentadas "a la morisca» sobre una alfombra. Una de ellas se lleva un pañuelo a los ojos para secar sus lágrimas, mientras sostiene con la mano derecha un instrumento musical de cuerda. Frente a ellas, un hombre arrodillado se fustiga con un cilicio el hombro desnudo '. La mayor parte de los observadores contemporáneos describirían su tema como una «exhibición» de penitencia en un interior burgués; pero a cualquier español del siglo XVII le llamarian poderosamente la atención varias cosas que contradicen semejante descripción: todas las mujeres, aun estando en un interior, visten sus galas, una de ellas tiene junto a sí una especie de guitarra y las otras tres llevan el cabello suelto y largo. Además, las pinturas que se desperdigan por las paredes no son retratos o Sagradas familias, sino que dos de ellas parecen representar escenas mitológicas, y una nos muestra a una santa arrodillada y penitente que nadie dudaría en identificar como María Magdalena. Galas, cabellos largos, música, fábulas mitológicas y santas penitentes convierten la habitación en un burdel, y a sus habitantes en prostitutas, aunque ninguno de estos elementos tienen en

\footnotetext{
Por razones que ignoramos, esta serie de estampas, compuesta por 35 ejemplares de importantes grabadores barrocos, como Juan de Noort, no formó parte de un libro hasta el siglo XVill, en que ilustro la obra de Manuel Trincheria: Pasmosa vida, hernicas virtudes, y singulares milagros del Abraham de la Ley de Gracia, patriarca y fundador de la sagrada Religion Hospitalaria, el glorioso San Juan de Dios. Nosotros hemos manejado la segunda edición impresa en Madrid en 1829. La estampa aparece junto a la página 151. Recientemente ha sido reproducida en Immagini della Spagna barocca. Roma, 1991, $\mathrm{n}^{\circ} 74$.
} 
nuestra época connotaciones explícitamente sexuales. El reverso de esta imagen es otra estampa, esta vez grabada por Matías de Arteaga en 1703, en cuyo fondo aparece una mujer arrodillada, desnuda de cintura para arriba y flagelándose. Aislado de su contexto, este detalle tiene para el ojo contemporáneo una clara significación erótica; y sin embargo describe el arrepentimiento de una religiosa por un pecado de lujuria ?

Los dos ejemplos anteriores a la vez que nos enseñan que los signos de reconocimiento utilizados en las artes plásticas de hace unos siglos son muy distintos a los actuales, nos avisan sobre la necesidad que tiene el historiador del arte de conocer el código que los rige. Pero también se desprende una enseñanza más profunda, como es que no basta con «leer» o interpretar los distintos elementos iconográficos para desvelar los significados de una obra, sino que es necesario también (entre otras cosas) acercarse a los resultados que nos ofrecen estas "lecturas» tratando de adoptar una perspectiva cercana a la de la época en que nació la obra. En nuestro caso no es suficiente saber que la primera escena describe un burdel y que la mujer que se fustiga lo hace por arrepentimiento; sino que hay que preguntarse, por ejemplo, por qué en el Siglo de Oro se utilizaban referencias para describir a las prostitutas que actualmente parecen herméticas, o qué es lo que ha cambiado en la concepción de la sexualidad en Occidente para que una imagen que sólo tenía entonces connotaciones religiosas las tenga ahora sexuales.

El estudio de los límites de lo que se consideraba deshonesto en el arte del siglo XVII afecta al tema mismo de la representación artística, y no sólo sirve para estudiar algunos problemas puntuales relativos a la historia de la pintura de la época, como son los que se refieren al desnudo femenino o a la difusión de la pintura mitológica, sino que también es una adecuada puerta para entrar en cuestiones que cada vez interesan más; entre ellas las que tienen que ver con los hábitos perceptivos del españoi de ese momento, con la existencia de un prejuicio a la vez social y moral contra la pintura colorista o con los cambios que han existido históricamente en el concepto de sexualidad. El tema es muy amplio, y aunque ha sido parcialmente tratado en estudios generales sobre el arte de esa época o en varias monografías, entre las que destacan las relacionadas con la pintura mitológica, falta un trabajo que lo aborde en todas sus consecuencias. No es nuestra intención hacerlo en este artículo, que sólo

La estampa, que narra la venganza de su amante, se incluye en JERONIMO DE SAN JOSÉ: Compendio de la vida del Beato padre San Juan de la Cruz. En Obras espirituales de San Juan de la Cruz. Sevilla, Francisco Leefdael, 1703, pág. 45. 
pretende mostrar unos cuantos caminos hasta ahora poco transitados, pero que pueden aportar nuevas perspectivas y pueden servir también para insistir en la necesidad de estudiar éste y todos los demás problemas relacionados con la representación artística teniendo en cuenta los hábitos visuales y las convenciones culturales de la sociedad en la que nace.

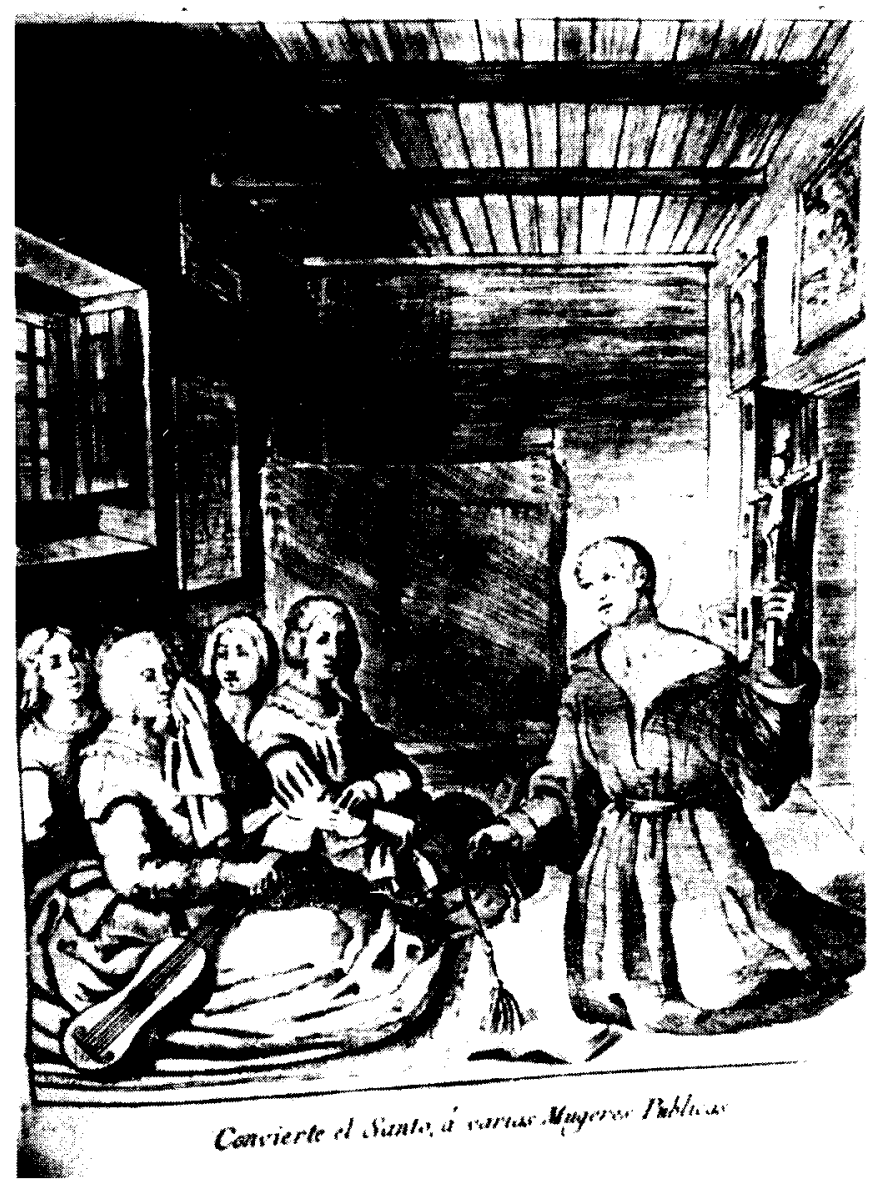

Fig. 1. Francisco Navarro: "San Juan de Dios en el interior de un burdel". Cobre, talla dulce. 
En concreto, nos interesa en estas páginas plantearnos y tratar de responder tres preguntas: ¿qué se consideraba pintura indecente?, ¿cómo veía el público este tipo de cuadros, y cuál era su actitud?, ¿existían objetos o acciones que aludían explícitamente al erotismo y que con el paso del tiempo han perdido su significado original? Trataremos de responder a algunas de estas cuestiones mediante el estudio de representaciones que entonces no se creían indecentes, pero que a partir de mediados del siglo pasado han sido utilizadas en ocasiones como vehículos eróticos, especialmente aquellas que tienen como protagonista a la Magdalena; y por medio del análisis de la que se consideraba imagen erótica por excelencia: un hombre en el regazo de una mujer.

Para entender los casos concretos que vamos a examinar es imprescindible tener en cuenta el contexto ideológico y social en el que nacieron. Es decir, que se produjeron en una sociedad teocéntrica, regida por un estado que se legitimaba a sí mismo no sólo en función de la tradición dinástica sino también por su papel de garante de la ortodoxia y del orden moral católicos; pero cuyos dirigentes fueron los coleccionistas más importantes del país de pinturas que entonces se calificaban como eróticas. Esta situación está en relación con varios fenómenos que se han apuntado en numerosos estudios anteriores, como la gran difusión que tuvo entre ciertos sectores la pintura veneciana del siglo XVI, o el comparativamente escaso cultivo de los temas mitológicos por parte de unos pintores locales que laboralmente dependian sobre todo de un cliente tan exigente en asuntos relacionados con el decoro como era la Iglesia. Pero a la vez, esta distancia entre las preferencias coleccionísticas de las clases poderosas y las restricciones morales eclesiásticas puede servir para situar en un contexto preciso el caso de algunos artistas que, al contacto con importantes coleccionistas, supieron en ocasiones substraerse a las exigencias de la Iglesia. El lector probablemente ya estará pensando en Velázquez, a quien el amparo real y cortesano permitió pintar cuadros como La Venus del espejo, singular en el panorama artístico español y aun europeo porque en él el desnudo no aparece justificado por una base narrativa explícita. Otro caso singular es el de Alonso Cano, que en su etapa madrileña - cuando entró en contacto directo con clientes cortesanos- probó con bastante fortuna el género, como muestra el magnífico dibujo de la colección Feduchi que parece representar a Dánae.

Los inventarios de bienes del siglo XVII prueban que los cuadros de tema erótico eran abundantes en las grandes casas; aunque dado que este tipo de pinturas tenían un trastondo literario muy del agrado de nuestros antepasados, y eran en general obra de maestros venecianos - que cultivaban el estilo de pintura que más se valoraba en el país- no parece 
fácil decidir si se coleccionaban por sus cualidades pictóricas, sus elementos narrativos, su erotismo o-como probablemente ocurría- por todo a la vez. El caso es que frente a esta tradición coleccionística que puede rastrearse ininterrumpidamente a lo largo de todo el Siglo de Oro y que se veía avalada nada menos que por el ejemplo de los sucesivos reyes, nos han quedado numerosas pruebas del rechazo de moralistas y teóricos del arte hacia la ejecución y adquisición de este tipo de cuadros. En el fondo, no se trata más que de una de las muchas contradicciones que definen la sociedad barroca española, y tiene un paralelo muy significativo en la enconada y continuada polémica sobre la licitud moral del teatro. Al igual que en lo que se refiere a esto último, el debate sobre la pintura indecente pasó por diversas fases, aunque dado el poder de aquellos que la coleccionaban casi siempre se resolvió en la práctica de forma contemporizadora, y son escasas las acciones concretas encaminadas a hacer efectivo el rechazo teórico.

La condena de las imágenes de carácter erótico llegó a convertirse en un tópico en la pluma de moralistas y tratadistas sobre arte. En el caso de los primeros, se trata de algo perfectamente comprensible; mientras que la postura de los que escribian sobre pintura no sólo se explica por un deseo de evitar contradicciones nunca queridas con la postura de la Iglesia, sino que se justifica también -como muchos otros problemas relativos a la práctica y teoría artísticas de esa época en España- en el contexto de la lucha que mantuvieron los más importantes pintores por el reconocimiento del carácter noble y liberal de la pintura. Éste se defendía invocando la utilidad que los cuadros tienen para la difusión de la religión y la defensa del estado, lo que convertía al pintor en un ser cargado de responsabilidad y, por eso mismo, de dignidad. Por eso, aunque circunstancialmente pudiera dedicarse a géneros "menores" y de escasa utilidad social como el paisaje o la naturaleza muerta, en ningún caso podía emplear su arte al servicio de las malas costumbres. Ya Séneca habia advertido sobre lo perniciosa que podia llegar a ser la pintura para la república; y lo mismo hicieron antes y después Aristóteles, Propercio, Plinio o san Agustín, alguno de los cuales llegó incluso a justificar la exclusión de este arte del sistema de las artes liberales por su capacidad corruptora. En la época que nos ocupa no falta el tema en ningún tratado de arte ${ }^{3}$; e incluso

Pero siempre se trae a colación para indicar que si bien circunstancialmente la pintura puede ser instrumento del desorden, en muchas más ocasiones lo es de religión. Las opiniones de los autores clásicos sobre pinturas deshonestas aparecen resumidas en JUAN DE PINEDA: Diálogos familiares de la agricultura cristiana. Ed. J. Meseguer, Madrid, Atlas, 1964, vol. IV, págs. 65-67; y 
aparece en algún libro de moral, como la Primera parte de las excelencias de la virtud de la castidad, que José de Jesús María escribió en 1601, donde se dice: "El arte de la pintura, es muy dispuesta para ganar o perder mucho con ella acerca de Dios: porque los pintores de figuras lascivas, se hazen participantes de los pecados, que por su causa se cometen, y de la fealdad y mal exemplo que con ellas recibe la República" ".

Aunque, como veremos en el caso de la Magdalena, es posible observar en la práctica pictórica entre mediados del siglo xvi y finales del siguiente una cierta evolución del concepto de "decencia", no ocurre lo mismo en lo que se refiere a los escritos artísticos y los tratados de moral, en ocasiones ambiguos a la hora de definir cuándo una imagen es o no decente. Así lo prueba un repaso cronológico de las ocasiones en que el tema fue abordado por la literatura o la legislación españolas.

Ya en una fecha relativamente temprana como 1574, cuando ya se había difundido ampliamente la pintura profana extranjera, los inquisidores aragoneses se mostraban preocupados por el tema y plantearon la publicación de un edicto para prohibir las representaciones de desnudos. Sin embargo, se les contestó que "se contentasen con recoger las que hubiera con indecencia notable" 5 .

Aunque la palabra «indecencia» tenía en esa época un significado mucho más amplio que el de "deshonestidad", y en un contexto artístico se refiere a excesos en la representación, en este caso ya existe una relación directa - como se haria frecuente décadas más tarde- entre indecencia y lascivia ${ }^{6}$. La respuesta es muy sintomática de la falta de criterios que existía a la hora de definir los límites de la lascivia pintada, y de la ambivalente postura respecto al desnudo, cuya representación al mismo tiempo que fue desaconsejada por tratadistas como Butrón o Pacheco, en ocasiones fue considerada admisible por algunos religiosos. Entre ellos figura Diego de la Vega, que en 1607 escribió que «el arte del ingenioso pintor en ninguna cosa se muestra como en hacer una imagen al desnudo» ? Juan de Cárdenas, por su parte, al narrar una visión que tuvo Damiana de

Sobre todo en JUAN INTERIAN DE AYALA: El pintor christiano, y erudito, o tratado de los errores que suelen cometerse trequentemente en pintar, y esculpir las Imágenes Sagradas. (1730). Madrid, Joaquin lbarra, 1782, vol. I, págs. 7-19.

Alcalá, Viuda de Juan Gracián, 1601, pág. 804

JuAn CaRRETE: "El grabado y la estampa barroca". En J. CarRete, F. Checa y V. Bozal: El grabado en Espana (Siglos xv-xviI). Madrid, 1987, pág. 434.

Sobre estos temas véase Palma Martinez-Burgos: idolos e imágenes. La controversia del arte religioso en el siglo xvi español. Salamanca, 1990.

Paraiso de la gloria de los santos. 1607, t. I, pág. 357. Citamos por Miguel Herrero Garcia: 
las Llagas, en la que se le aparecía un hombre desnudo, advierte que la imagen no atentó contra su pureza, pues Dios, como buen pintor, supo "templar las líneas, y perspectiva del cuerpo humano, de manera que ni los ojos más lascivos encuentren cosa que pueda provocarlos» ".

A menudo se ha tratado de la religiosidad española del Siglo de Oro como un sistema monolítico en el que apenas existian diferencias y discrepancias. Pero a pesar de que es indudable que la mayor parte de la población compartía numerosos dogmas, creencias y algunos patrones de comportamiento, también es cierto que dentro de los límites dogmáticos existía una gran variedad de posturas y expresiones que no era sino el reflejo de una sociedad extraordinariamente compleja en su composición, sus actitudes y sus aspiraciones ${ }^{3}$. De esta variedad puede darnos una ligera idea la variedad de contextos en los que aparecen referencias a las pinturas deshonestas. Así, su casuística no se acaba con el debate sobre si puede o no haber desnudos admisibles; sino que hay algunos escritores que van más allá y en vez de aislar la condena a las pinturas lascivas la enmarcan en el problema más general de la superfluidad de cualquier cuadro de cuya contemplación no derive una enseñanza religiosa o un ejemplo civico. Eso hace, por ejemplo, Francisco Arias en su Segunda parte del aprovechamiento espiritual, de 1588, donde dedica varias páginas a rechazar un género tan extendido y en general poco criticado como el retrato profano, al que tacha de vehículo para la vanidad: « $Y$ mas quando las personas cuyos son los retratos son amadas con amor sensual: ¿qué es tenellos delante de los ojos, sino encender más la llama de las aficiones desordenadas?". Incluso va más allá, y condena el simple placer de mirar pinturas "no por otra necessidad ni provecho, sino por solo el contento, y deleyte de mirarlas». Pero lo más curioso es que inmediatamente después de hablar del "placer de ver» se refiere a las pinturas deshonestas; con lo que establece inconscientemente una relación muy significativa entre calidad pictórica y pintura indecente, de la que más adelante trataremos ${ }^{10}$.

Contribución de la literatura a la historia del arte. Madrid, 1943, pág. 215. No debemos olvidar, sin embargo, que para algunos escritores desnudo y pintura lasciva eran prácticamente sinónimos.

* JuAN de CARDEnAS: Historia de la vida, y virtudes de la venerable virgen Damiana de las Liagas. Sevilla, Juan Cabezas, 1675, págs. 432-433. Sobre el desnudo en la teoria española de arte posterior a Trento vease Justo OCTAvio PICON: Observaciones acerca del desnudo y su escasez en el arte español. Madrid, 1902; y Chistina Canedo Arguelles: Arte y teoria: La Contrarreforma y Espana. Oviedo, 1982, págs. 73-74, que se centra en las opiniones sobre el Juicio Final de Miguel Angel.

Sobre el tema es fundamental JULIO CARO BAROJA: Las formas complejas de la vida religiosa. Madrid, 1985.

1.) Valencia, Pedro Patricio Mey, 1588, págs, $407-410$ y 402. 
La abundancia con que a partir de la segunda mitad del siglo XVI surgen en España los escritos y las iniciativas tendentes a combatir la pintura deshonesta ha de verse en relación con el incremento del gusto por las pinturas mitológicas, con la doctrina artística que se codificó en el Concilio de Trento y con la legislación eclesiástica que se promovió en Roma sobre todo este asunto. En lo que se refiere a esta última, destaca la inclusión en el Indice promovido por Clemente vIII en 1596 de la prohibición de «imágenes deshonestas y lascivas; aunque sean solamente en estampa». Poco antes, en 1593, Antonio Possevino publicó Tractatio de Poesi et Pictura ethica, del que para el tema de estas páginas interesa un párrafo en el que se hace eco de la proliferación de pinturas deshonestas en España y la achaca a la venganza del demonio por el importante papel que jugó el país en la evangelización de América ".

En el inicio del siglo siguiente aparece la Primera parte de las excelencias de la virtud de la castidad, de José de Jesús María, que fue una guía utilizada por todos los que posteriormente se interesaron por este campo, y cuyo capitulo XV, bastante extenso, se titula: "De quanto dañan a la pureza pinturas deshonestas, donde puedan ser miradas" ${ }^{12}$. En él apunta las principales cuestiones en torno a las cuales girará el debate sobre el tema; y lo hace con un método muy escolástico, que mezcla referencias a autores clásicos con reflexiones personales de carácter moral y social y con algunos relatos que le sirven para apoyar su tesis. Para él —como para muchos de sus contemporáneos- la vista es mucho más eficaz y persuasiva que el oído, y por lo tanto la pintura deshonesta es mucho más peligrosa que la literatura, ya que además "las palabras pintan una cosa ausente o ya pasada, pero las pinturas la figuran presente". Por eso, incluso en el Libro de la Sabiduria se alerta sobre el poder seductor del arte. Además este tipo de imágenes es nocivo no sólo porque corrompen las buenas costumbres e incitan a la lujuria sino también, y sobre todo, porque al representar mayoritariamente escenas de la mitología clásica promueven la idolatría. Al llegar a este punto, el autor recurre a Possevino, aunque sin citarlo, para explicar la presencia de pintura mitológica en España, cuya proliferación describe así: "Y hase introducido esto tan a priessa, que ya están llenas de esta inmundizia las antecámaras y galerias de los palacios de los Príncipes, y los aposentos y dormitorios de la gente de todos los demás estados: porque tienerı este adorno indecente, por más alegre y agradable,

Los comentarios de Possevino fueron aprovechados en varios libros de moral españoles, como en luisa Maria de Padilla: Excelencias de la castidad. Zaragoza, Pedro Lanaja, 1642, pág. 602 .

Alcalá, Viuda de Juan Gracián, 1601, págs. 797-805. 
que otra tapicería alguna. Y quanto las pinturas están con mayor desnudez $\mathrm{e}$ indecencia, tanto son más preciadas y buscadas". Tras abordar ligeramente el tema de la indecencia en las representaciones sagradas, ilustra toda su argumentación con una divertida historia protagonizada por dos religiosos que tuvieron que hacer noche en una residencia campestre. Uno de ellos mientras rezaba sus oraciones vio pasar en procesión varios demonios turiferarios. Tras agarrar y amenazar a uno de ellos, consiguió que le confesara que se dirigían a una sala para adorar una pintura, "por ser deshonesta, y por ser el altar donde las almas se nos ofrecen en toda esta comarca". A la mañana siguiente, el religioso, pretextando "ser muy aficionado a la pintura" consigue que el señor de la casa le enseñe su colección, entre la que descubre un cuadro con "una muger desnuda, abraçada con una águila y con semblante tan deshonesto, que a qualquiera hombre inquietara». Tras verla, trata de convencer al noble que se deshiciera de esta Leda, a lo que éste respondió "que eran escrúpulos impertinentes de gente indocta; porque allí avían estado muchos hombres religiosos y letrados, y le avían alabado mucho la pintura; y que tenían razón, por ser de uno de los artífices mas primo que avía avido en Europa». El cielo castigó su respuesta haciéndolo morir sin confesión dos meses después.

Lo que hace tan interesante al relato es que incluye muchas de las coordenadas en las que hay que enmarcar el tema de la pintura deshonesta en la España del Siglo de Oro. Aparece así la aprobación de algunos religiosos y la reprobación de otros, la mitología, la idolatría, el coleccionismo de la nobleza y la relación entre calidad artística y eficacia persuasiva. Italia es otro elemento importante que sirve para vincular la anécdota con lo que sabemos sobre la pintura mitológica que se coleccionaba en España, pues de allí procedía tanto la mayor parte de ésta como la Leda lasciva, que había sido regalada al padre del caballero protagonista por un gran príncipe transalpino.

El capítulo incluye también unos comentarios de gran valor sobre la responsabilidad del pintor, que con el mal ejercicio de su arte ofende a Dios y a los santos y actúa como servidor del demonio. Para fray José, "aunque ofenden mucho a Dios las personas que tienen en sus casas figuras semejantes, para ocasión de malos pensamientos y deseos de quien las mira; más gravemente pecan los que las pintan, y se les ha de tomar sobre ello quenta rigurosa en el tribunal divino: porque aviendo de ayudar con su arte, como buenos hijos a sus repúblicas, las defraudan de la honestidad y pureza tan necessaria para su dignidad y hermosura, y para la utilidad de sus ciudadanos y vezinos". $Y$ para que a nadie le quede duda de esto narra el caso de un pintor que hizo donación de sus bienes a un convento en el que habia estado pintando, y poco después de morir se 
le apareció a un fraile rodeado de las llamas del purgatorio, adonde habia llegado porque «aunque avia siempre pintado cosas de devoción, pintara una vez una figura deshonesta de una fábula, a instancias de un señor, a cuyos ruegos no avía podido resistir, y que por esto quedara condenado eternamente, si los santos cuyas imágenes avia pintado, honesta y devotamente, no intercedieran a Dios por él: y que assí la pena del infierno, le avía sido conmutada en pena del purgatorio, de donde no quería Dios que saliesse hasta que aquella figura se quemasse». El cuadro en cuestión representaba a Venus y Adonis (como veremos, la escena erótica por excelencia), y por supuesto acabó en la hoguera. Tras narrar esta anécdota, recomienda a los confesores que examinen detenidamente a los artistas para comprobar si realizan este tipo de obras, pues de su actividad "pende una gran parte de la honestidad y templança de una república».

José de Jesús Maria carga la mayor parte de la responsabilidad sobre las pinturas indecentes en sus autores, y no en sus consumidores o en las autoridades que no ponian el necesario interés para controlar el tema. Pero no es el único que actúa así. Simón de Rojas, por ejemplo, una de las figuras claves del mundo religioso cortesano de las primeras décadas del siglo XVII, cultivó - según su biógrafo- especialmente la amistad de los pintores con objeto de que no hiciesen "retratos que solicitan algunos para traer consigo de grande riesgo de la vida del cuerpo y del alma; muchos pusieron algunos en la celda del santo desterrando los ídolos, y deidades mentirosas que torpemente ciegos adoravan" "13. Tratadistas como Carducho o Pacheco también insisten en las responsabilidad del pintor; y habria que preguntarse si esta situación no obedece sobre todo a que era mucho más fácil presionar a un grupo profesionalmente desprotegido y siempre dependiente desde el punto de vista económico e ideológico de la Iglesia que a unos coleccionistas que pertenecían sin excepción a las clases poderosas y no sólo tenían capacidad y recursos suficientes para substraerse de esta influencia, sino que veian incluso avaladas sus aficiones por la misma cabeza de la monarquía católica. El caso es que, como ya se ha dicho, los pintores españoles apenas trataron los temas mitológicos ${ }^{14}$ y las grandes colecciones abundaban en cuadros que representaban las idas y venidas de los dioses del Olimpo.

Aún así, no faltaron otras iniciativas para vedar la difusión de este tipo de obras. El ya citado Simón de Rojas pidió al cardenal don Bernardo de

\footnotetext{
Fray Francisco de Arcos: Primera parte de la vida del V. y Rmo. P.M. Fr. Simon de Roxas. Madrid, Julián de Paredes, 1670, pág. 298.

- Es fundamental Rosa LoPez TORRIJos: La mitologia en la pintura española del Siglo de Oro. Madrid, 1985.
} 
Rojas, arzobispo de Toledo, que prohibiese las pinturas deshonestas, y éste despachó un edicto "para que no se consientan las que tienen lascivia o sensualidad" ' ${ }^{5}$. Semejante petición hizo fray Bernardino de Villegas, autor de La esposa de Cristo, donde además de establecer implícitamente una reveladora equiparación entre "profano" y "deshonesto" y de escandalizarse ante la abundancia de este tipo de cuadros en "las galerías y camarines de mucha gente principal», aboga por la creación de un tribunal que, al igual que el que ya existía para los libros, examinara las pinturas ${ }^{16}$.

El intento más serio que se hizo en el siglo XVII para abordar el tema de las pinturas deshonestas es la Copia de los pareceres y censuras de los reverendísimos Padres Maestros y Señores Catedráticos de las insignes universidades de Salamanca, y de Alcalá, y de otras personas doctas, sobre el abuso de las figuras, y pinturas lascivas y deshonestas, que se muestra, que es pecado mortal pintarlas, esculpirlas y tenerlas patentes donde sean vistas ${ }^{17}$, publicada en Madrid en 1632 probablemente por iniciativa del portugués don Francisco de Braganza. Las posturas de sus autores son variadas, y entre ellas no faltan las sensatas. En general se está de acuerdo en desaconsejar la exposición pública de pinturas lascivas, aunque algunos advierten que sólo han de considerarse como tales las que realmente y sin duda lo son (como las que representan aigunas escenas mitológicas) y no las que una mente fácilmente impresionable y predispuesta pudiera considerar como tales ("por figura lasciva se entiende la que de suyo lo es..., no la que sólo es lasciva por la mala intención de quien la mira», como dice fray Benito de la Serna). También hay un general consenso a la hora de no incluir en la calificación de lascivos aquellos cuadros que aunque presentan desnudos ya forman parte de la tradición iconográfica cristiana. Mucho más dispersas son las opiniones sobre las acciones que deberían llevarse a cabo para encarar el tema; y así, mientras que algunos abogan por una prohibición formal, otros advierten que pecan gravemente quienes las pintan o coleccionan, y la mayoría sólo insiste en la inconveniencia de exponerlas públicamente.

La Copia de los pareceres es un documento revelador de la importancia que estaba tomando el tema en los años treinta, y sus promotores vieron

Arcos: Primera parte... pág. 298.

Bernardino de Villeggas: La esposa de Cristo. Murcia, 1635, págs. 436-437.

Madrid, Viuda de Alonso Martin, 1632. Se reprodujo en Francisco Calvo Serraller, Teoria de la pintura del Siglo de Oro. Madrid, 1981, págs. 241-258, de donde la citamos nosotros. En la biblioteca de la Hispanic Society de Nueva York existe un escrito de fray Hortensio Félix Pacavicino sobre el mismo tema, que no llegó a publicarse y al que no hemos tenido acceso, pero que - dado el interés que siempre mostró su autor por la pintura- probablemente sirva para conocer los puntos de vista que sobre el asunto tenian aficionados y coleccionistas. 
pronto cumplidas sus aspiraciones de que se controlara legalmente la producción o difusión de las pinturas deshonestas. Aunque uno de sus escritores, Diego Fernández, da a entender que un Inquisidor General habia intentado infructuosamente que se prohibieran este tipo de obras ${ }^{18}$, en 1640 las ordenanzas de los pintores de Pamplona establecían el nombramiento de un veedor "para que vigile las obras de pintura que entran desde Francia porque algunas de ellas están prohibidas por la Inquisición, o provocan a deshonestidad " ${ }^{19}$, y ese mismo año en los Indices inquisitoriales se prohibe expresamente la creación e importación de las imágenes deshonestas ${ }^{20}$. Los inquisidores españoles en esto de nuevo se mostraron más papistas que el papa, pues éste, que era Urbano vIII, se limitó en 1642 a prohibir que «en ninguna iglesia, de qualquier modo que se entienda, ni en sus portadas, o atrios, se expongan a la vista imágenes profanas, ni otras indecentes, ni deshonestas" "2. Aunque los datos que conocemos sobre el control artístico de la Inquisición española se refieren fundamentamente a imágenes sagradas heterodoxas ${ }^{22}$, no faltan los que afectan al tema de las pinturas deshonestas. Así, en 1645 se hizo un registro de los bienes de los extranjeros que residian en La Orotava, y a los inquisidores no les parecieron convenientes unos cuadros que representaban a damas con el pecho descubierto 23. Con el paso del tiempo se hacen más corrientes este tipo de noticias, que durante el siglo XvIII fueron bastante abundantes ${ }^{24}$.

\footnotetext{
i* Copia de los pareceres..., pag. 255. El texto de expurgatorio inquisitorial dice: « $Y$ para obviar en parte el grave escándalo y daño (...) que ocasionan las pinturas lascivas mundanas mandamos: Que ninguna persona sea osado a meter en estos yernos, imágenes de pintura, láminas. estatuas u otras esculturas lascivas, ni usar de ellas en lugares públicos de plazas, calles o aposentos comunes de las casas. $Y$ asimismo se prohibe a los pintores que las pinten, y a los demás artífices, que las tallen ni hagan, so pena de excomunión mayor latae sententiae, canonica monitione praemisa, y de quinientos ducados por tercias partes, para gastos del Santo Oficio, jueces y denunciantes, y un año de destierro a los pintores y personas particulares que las entraren en estos reynos o contravinieren en algo a lo referido". Citamos por Justo OCTAvio PICÓN: Observaciones..., pág. 35.

1:i López TORRIJos: La mitología..., pág. 21.

Alfonso Rodriguez G. de Ceballos: "La repercusión en España del decreto del Concilio de Trento acerca de las imágnes sagradas y las censuras al Grecon. Studies in History of Art, t. XIII (1984), pág. 154.

interiản: El pintor christiano..., t. I, págs. 22-23

Sobre este tema véase JUAN CARAETE: "Les estampes hetérodoxes en Espagne au XVII" siécle et au debut de XIX" siécle". Gazette des Beaux Arts, t. XCIV (1980), págs. 169-182; y V. PINTO CAESPO, "La actitud de la Inquisición ante la iconografía religiosa". Hispania Sacra, $t$. $X X X \mid$ (1978-1979), págs. 285-322

"Margatita Rodriguez Gonzalez: "Pintura e Inquisición en Canarias". Cuadernos de Arte $\theta$ lconografía, t. II-4 (1989), pág. 94

Además del artículo anterior, véase, por ejemplo, Juan BLÁzQuez Miguel: Madrid, Judíos, herejes y brujas (El Tribunal de Corte 1650-1820). Toledo, 1990, que trae algunos curiosos casos.
} 
Todos los que escriben contra las pinturas deshonestas en el Siglo de Oro tienen bastante claro que a este género pertenecen las que representan ciertos episodios de la mitología clásica. Sin embargo, no existe la misma unanimidad cuando se trata de juzgar obras de carácter religioso que por su temática o el aspecto de sus personajes pueden parecer de contenido ambiguo. En general se puede decir que la tradición iconográfica había avalado muchas de estas representaciones y sirvió para que, por ejemplo, se admitiesen desnudos en contextos sagrados. Cárdenas, por ejemplo, en 1675 indica que "sabe un pintor disponer la imagen de un San Sebastián desnudo, de suerte, que provoque a devoción, y no a indecencias" 25; y muchos de los que intervinieron en la Copia de los pareceres... demuestran ser en este asunto relativamente abiertos. Así, fray Benito de la Serna dice que «Pinturas desnudas ha usado la Iglesia en los Mártires, y historias antiguas, donde, o la hermosura nos mueve a alabança del Criador, o los tormentos a la imitación de sufrimiento" ${ }^{26}$; y Francisco Corneịo afirma que aunque algunos se escandalizan ante la vista de personajes de historia sagrada que aparecen desnudos, más se debe a su "complexión natural" o a su "malicia" que a la naturaleza de estas pinturas ${ }^{27}$.

Un repaso a los catálogos de pinturas españolas de esa época y a las colecciones contemporáneas nos demuestra que hubo cierta libertad a la hora de elegir como temas santos que se representaban semídesnudos o escenas bíblicas de carácter erótico. Sin embargo, no faltaron voces que advirtieron sobre el grave peligro de una representación inadecuada de estos temas. José de Jesús María alerta contra quienes hacen «imagines de los santos con tanta impropiedad y desnudez, que más mueven algunas vezes a torpes sentimientos, que a piedad y devoción» 28; y hay varios tratadistas de arte muy sensibles al tema, como Palomino, quien narra la historia de un cartujo al que tuvieron que quitar de su celda una perturbadora imagen de la Virgen, 10 que recuerda una de las tramas de El monje, la novela gótica de Lewis ${ }^{29}$.

Interián de Ayala, en su influyente Pintor christiano y erudito va más allá, y desaconseja genéricamente la representación de escenas comprometidas del Antiguo Testamento, como la de las hijas de Loth, José y la mujer del faraón, Bethsabé o Susana y los viejos, y cuenta con pena que un celebre pintor español a quien no identifica se especializó tanto en este tipo de obras que cuando tuvo que pintar otras escenas nunca alcanzó

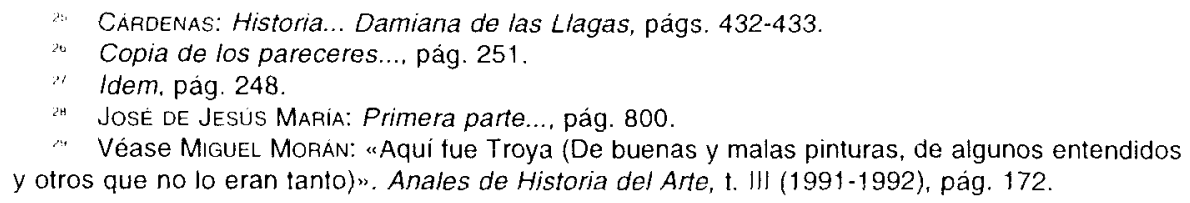


los niveles de calidad que obtenía al enfrentarse a estos personajes bíbli$\cos ^{30}$. El catálogo de indecencias de Interián no se queda alli, e incluye Vírgenes "pintadas caído su cabello rubio, desnudos su cuello, y hombros, y aun sus purísimos, y virginales pechos, y otras veces con los pies enteramente descubiertos", Niños Jesús demasiado creciditos para estar desnudos, mártires sin ropa o un San Sebastián que en Italia perturbaba a las mujeres. Aunque tanta insistencia tiene probablemente un fin retórico y de su celo por velar para que los artistas se ajustaran a las leyes del decoro podemos encontrar precedentes en numerosos tratadistas, su tono es más agrio que el de escritores del siglo anterior, y probablemente traduce un ligero cambio en la actitud ante las representaciones sagradas.

De entre todos los santos cuya historia daba la posibilidad de representar un desnudo hay uno cuya fortuna artística y literaria puede sernos de gran utilidad tanto para rastrear algunos de los cambios que han existido en el concepto de sexualidad en Occidente como para acercarnos al estudio de los hábitos de percepción artística del español del Siglo de Oro. Se trata de María Magdalena, uno de los personajes más representados por el arte cristiano desde tiempos medievales. Pero si hasta el Renacimiento los episodios de su vida que en mayor número de ocasiones atrajeron la atención de pintores y escultores son los relacionados con la Pasión y los inmediatamente anteriores y posteriores a este suceso, a partir de mediados del siglo XVI la faceta que más interesó fue su penitencia. Mâle interpretó el fenómeno relacionándolo con el interés de la iglesia contrarreformista por la doctrina del arrepentimiento y por difundir la práctica de la confesión ${ }^{31}$. Y la verdad es que la Magdalena, un ejemplo vivo de la posibilidad que tiene siempre el cristiano de arrepentirse independientemente de la gravedad de sus faltas, compendia con

INTERIAN: El pintor christiano..., págs. 18-19. La cita dice: "¿Pero quáles son las historias sacadas de la Sagrada escritura, que nos dexó escritas, o pintadas aquel buen retórico pintor? No otras ciertamente, sino las que podian incitar, y avivar más el fuego de la concupiscencia. Tales son las pinturas de las hijas de Loth enteramente desnudas, y sin el menor pudor, ni recato, dando vino a su viejo padre con mucha abundancia para embriagarle, y hacerle cometer el abominable incesto: tal es también la pintura de aquella muger de Egipto, provocando al casto Joseph al adulterio: tal la de Bethsabé, que se prostituia al antojo, y concupiscencia de David: tal la de Susana, quando se estaba lavando; y otras de este género: y estas mismas son las que quiso pintar antes que otras decentes, y honestas, un célebre pintor español (que es el otro de los dos, de quienes sin decir sus nombres, hice poco hace mención) con mucha valentía de pincel, aunque malisimamente aplicada: y lo que es de admirar, o mucho más de sentir, que si alguna vez pintaba otros hechos, o historias, se echaba menos en ellas aquel primor, y delicadeza del arte, que resaltaba en las antecedentes".

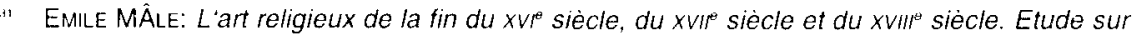
liconographie après le Concile de Trente. Paris, 1951, págs. 67-70. 
su biografía un modo de comportamiento que no es sólo similar al de muchos españoles del Siglo de Oro sino que puede en cierto sentido considerarse paradigmático de esa sociedad. La tensión continua entre pecado y arrepentimiento define no solamente el carácter de numerosos personajes literarios, sino también la personalidad de muchos de los españoles de los que se conoce su perfil psicológico. Miguel de Mañara, que tras una juventud tumultuosa dedicó su madurez y vejez a enterrar a los muertos y atender a los enfermos, es un ejemplo conocido por todos; pero también Lope de Vega, eterno pecador arrepentido en cuya vida se alternan las etapas de intensa actividad erótica con las de sublimación religiosa, una de las cuales le llevó a tomar las órdenes sagradas; o fray Francisco de Pamplona, en el mundo don Tiburcio de Redín, que de fiero militar se convirtió en activo misionero. En cierto sentido la Magdalena representa el casuismo, un método de análisis moral defendido fundamentalmente por los jesuitas que tiene como punto de partida la necesidad de juzgar las acciones no según patronos rígidamente establecidos de antemano sino teniendo en cuenta las infinitas circunstancias sicológicas, sociales o morales que están detrás de ellas; lo que condujo a una flexibilidad a la hora de juzgar los pecados (excepto cuando afectaban a cuestiones dogmáticas) mayor de la que habitualmente se piensa. Además, el casuismo con su especie de relativismo ayudó a facilitar el tránsito entre el pecado y el arrepentimiento.

Para el español del Siglo de Oro, que vivía en una sociedad dura y pasional, la Magdalena significaba ante todo la certeza de que siempre era posible el arrepentimiento; y por eso es con diferencia la santa cuyas imágenes en mayor número de ocasiones se registran en inventarios de bienes particulares en el siglo xvII. En Murcia supone casi el veintidós por ciento del total de las santas ${ }^{32}$; en el Madrid de la segunda mitad del siglo es también la advocación femenina más numerosa ${ }^{33}$; y en las colecciones documentales de Mercedes Agulló su nombre aparece con mucha mayor frecueñcia que el de personajes también muy queridos, como santa Catalina o santa Teresa ${ }^{34}$. Paralelamente, María

Jose Carlos Aguera: Pintura y sociedad en Murcia en el siglo xvil. Murcia, un centro del Barroco español. Murcia, 1994, pág. 413.

Jesus Bravo Lozano: "Pintura y mentalidades en Madrid a finales del siglo Xvil». Anales del instituto de Estudios Marileños, t. XVIII (1981), págs. 193-220. Entre las santas sólo la Verónica esta tan bien representada como Marja Magdalena en las colecciones madrileñas de esa época.

- En sus Documentos para la historia de la pintura española. Madrid, 1994, hay 29 referencias a la Magdalena frente a 14 a santa Catalina y 11 a santa Teresa; en Más noticias sobre pintores madrileños de los siglos XVI al XVIII. Madrid, 1981, la relación es de 32, 16 y 17; y en Noticias sobre pintores madrileños de los siglos xvi y xvil. Granada, 1978, es de 28, 25 y 14. 
Magdalena tuvo una gran fortuna literaria que ha sido objeto de un estudio reciente ${ }^{35}$ y que se tradujo en numerosos poemas, en obras de teatro de Vélez de Guevara o Lope de Vega y, sobre todo, en la admirable La conversión de la Magdalena, de Malón de Chaide.

La santa proporcionaba, con su biografía y sus atributos físicos, grandes oportunidades a los artistas de representar la imagen de una mujer hermosa y en general ricamente ataviada protagonizando escenas en ocasiones de gran fuerza dramática y emocional. Es difícil, por ejemplo, encontrar en todo el repertorio iconográfico cristiano un episodio que se preste más a la plasmación del lirismo y la emoción contenida que el Noli me tangere, que se desarrolla invariablemente en plena naturaleza y cuyos protagonistas intercambian un delicado diálogo gestual, como sabe todo aquel que ha visto alguna vez el cuadro de Correggio del Prado o la deliciosa tablita de Juan de Flandes para el retablo de Isabel la Católica. En el caso de las alusiones a la Magdalena penitente, que, como dijimos, son las más numerosas en el siglo XVII, la narración hagiográfica no ofrecía muchas posibilidades de variación a los artistas, pero éstos se las ingeniaron para dejarnos un catálogo de representaciones relativamente variado, aunque siempre con el denominador común de la hermosura física de la santa.

De entre las numerosas representaciones de María Magdalena penitente que nos ha dejado el Siglo de Oro nos interesan para el tema de estas páginas aquellas en las que ésta, por su desnudez o su actitud, pueda tener para los ojos actuales una efectividad erótica similar a la que tienen las pinturas mitológicas que en esa época se consideraban deshonestas. $Y$ hay que tener en cuenta que casi todas de las que vamos a tratar fueron destinadas a lugares abiertos al culto y consecuentemente pudieron ser contempladas por una masa indiscriminada.

A partir de la segunda mitad del siglo XVI comienza a difundirse el tipo de Magdalena en actitud penitente que se haría tan frecuente en la centuria siguiente. Sin embargo, aunque de esos años nos quedan algunas de las imágenes más hermosas y en las que se nos muestra de una manera más verídica el arrepentimiento, como las bellisimas de El Greco, también es posible encontrar ejemplos en los que la santa, aunque acompañada de los atributos de su vida eremítica, se encuentra en una actitud más bien

\footnotetext{
- Mafia Helena Sanchez Ortega: Pecadoras de verano arrepentidas en invierno, Madrid, 1995. Incluye tambien un resumen de lo expuesto por Mâle y Réau sobre la iconogratia de la Magdalena y de otras santas penitentes.
} 
relajada. Eso ocurre en la lánguida y deliciosa Magdalena del convento de Santo Domingo el Real de Toledo, que la representa recostada en un paisaje y hojeando pensativa un libro que se supone devoto. Descubre los pies y parte de su largo y suelto cabello, y envuelve el resto de su sinuoso cuerpo en una espléndida túnica blanca. A pesar del crucifijo que tiene frente a si, el libro ante el que parece meditar y alguna escena de su vida posterior que se representa a lo lejos, prevalece ante todo una sen-

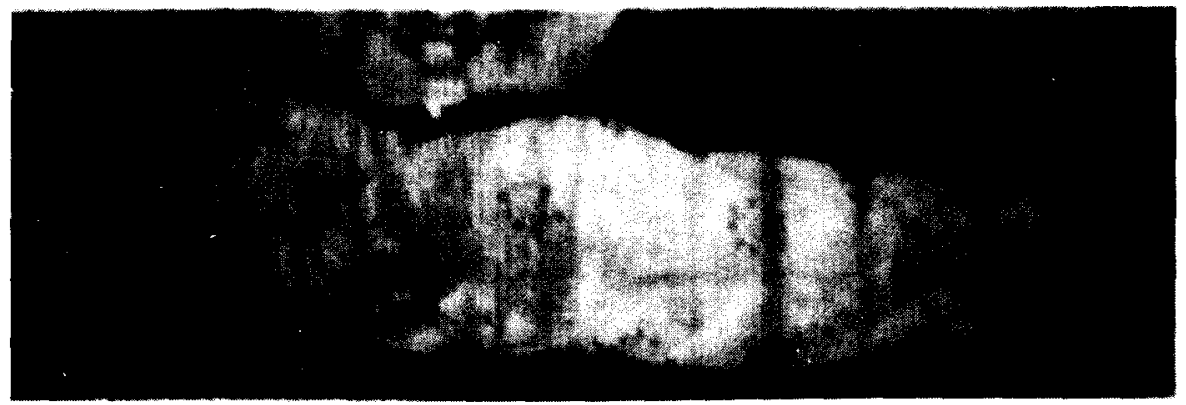

Fig. 2. Anónimo: "Magdalena arrepentida". Toledo, Santo Domingo el Real.

sación de lánguido abandono que apenas deja resquicio al arrepentimiento ${ }^{36}$. Por su actitud, la santa está mucho más cercana a las finas y delicadas magdalenas que pueblan los bancos de los retablos de final del Gótico y principios del Renacimiento que a las atormentadas arrepentidas contrarreformistas.

Esta obra sigue probablemente el modelo impuesto por un cuadro que algunos atribuyen a Gaspar Becerra (Museo del Prado); aunque se ha suprimido todo patetismo. También de la segunda mitad del siglo XVI y derivada de un modelo ajeno es la Magdalena de Rolán de Moys, de la iglesia parroquial de Codos (Zaragoza), que se inspira en una obra de Tiziano muy difundida por medio de copias y estampas y a la que ha sometido a un importante proceso de transformación. La santa no mira implorante al cielo, sino que dirige su rostro lloroso al espectador, y el pintor de origen flamenco en vez de cubrir la mayor parte del

36 Balbina Martinez Caviro: Conventos de Toledo. Madrid, 1990. pajgs. 114-115. 
busto descubre claramente uno de sus pechos. El tipo físico también es muy distinto, y mientras que Tiziano pinta una mujer rotunda que es todo expresividad, Rolán de Moys prefiere evocar la imagen frágil de una santita gótica ${ }^{37}$.

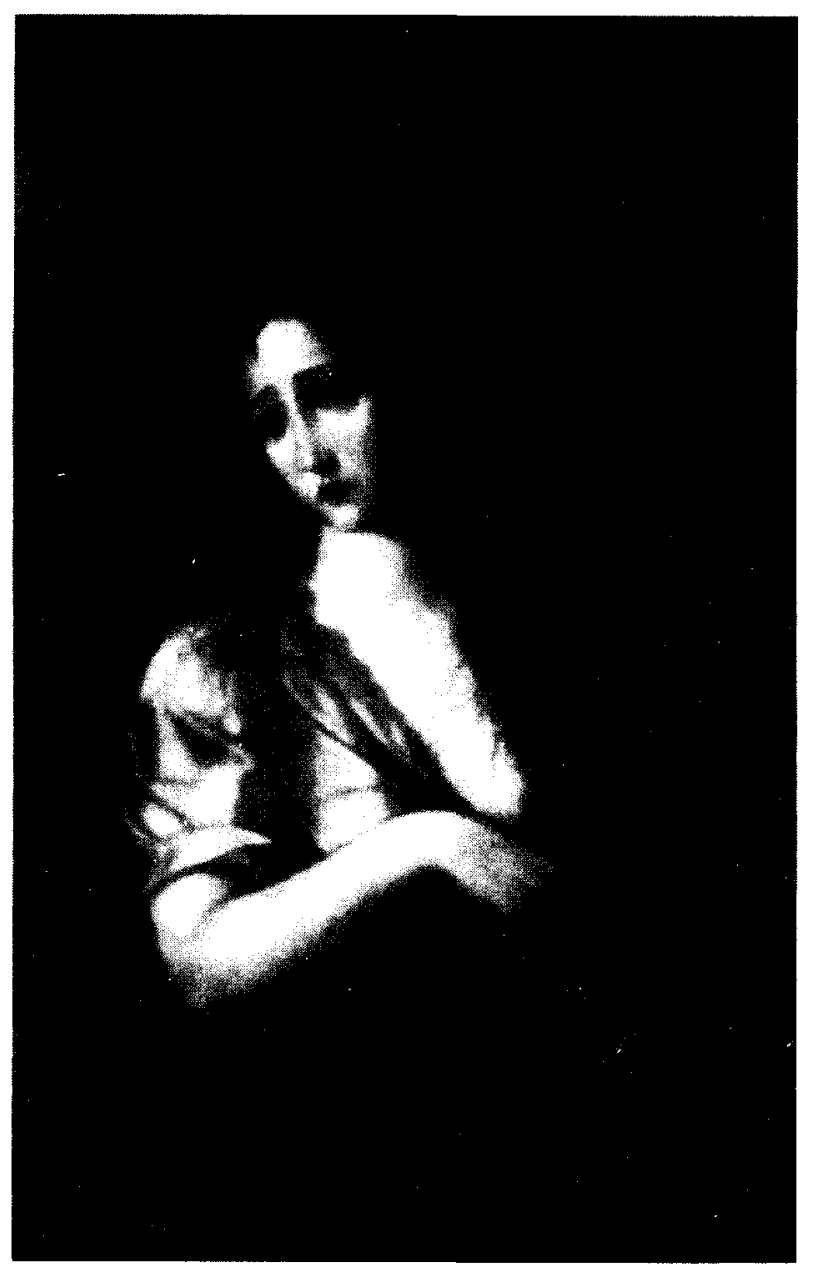

Fig. 3. Rolán de Moys: “Magdalena arrepentida». Codos (Zaragoza), Parrcquia de la Magdalena.

Sobre esta pintura véase el catálogo de la exposición El espejo de nuestra historia, Zaragoza, 1991, pág. 538. Muy parecida es la Magdalena de Luis Morales de la Clerecia de Salamanca. 
No son estas las únicas imágenes que pueden chocar actualmente a quien conozca la rigidez con que se expresaron algunos en esa época contra la necesidad de velar por la decencia en la representación de los santos. Una Magdalena anónima de Villalba del Alcor (Huelva) aparece en posición casi frontal y la completa desnudez de su torso sólo se encuentra interrumpida por los largos cabellos que cubren parte de sus pechos y por las joyas con que, coqueta, engalana las muñecas, los antebrazos y la cabeza ${ }^{38}$. También se mostró muy generoso a la hora de plasmar los rasgos anatómicos de la santa Luis de Carvajal en su cuadro del Museo de Santa Cruz de Toledo (1579), en el que existe un inquietante contraste entre la compunción que enseña Magdalena en su rostro y la rotundidad carnal de su cuerpo ${ }^{39}$.

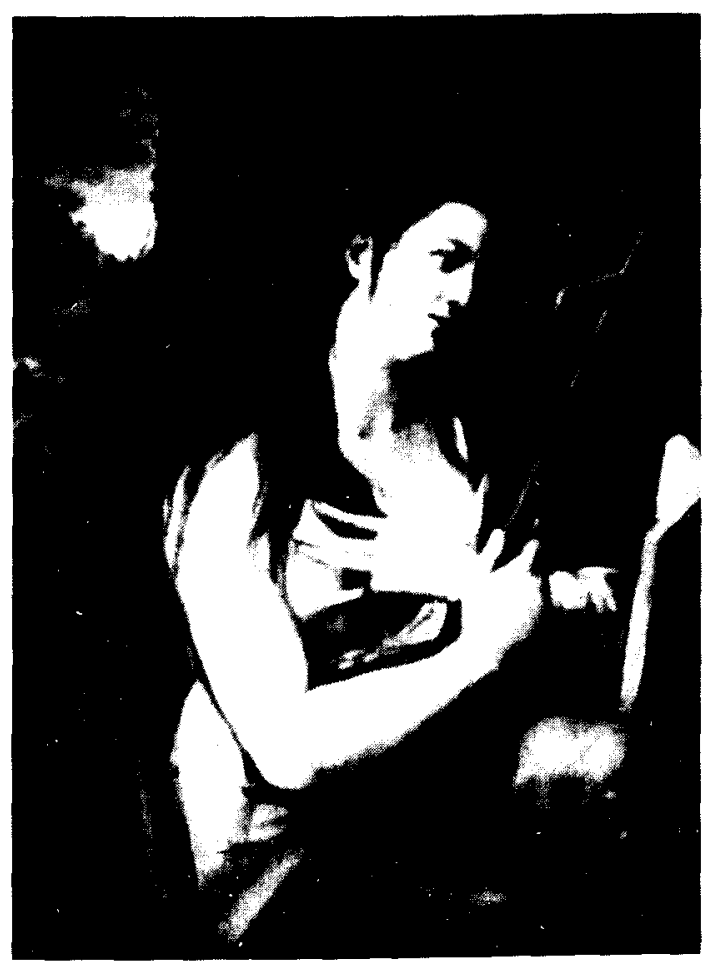

Fig. 4. Luis de Carvajal: "Magdalena arrepentida”. Toledo, Museo de Santa Cruz.

Martinez-Burgos: Idolos e imágenes..., págs. 79-86.

14. Catálogo de la exposición El Toledo de El Greco. Toledo, 1982, pág. 150. 


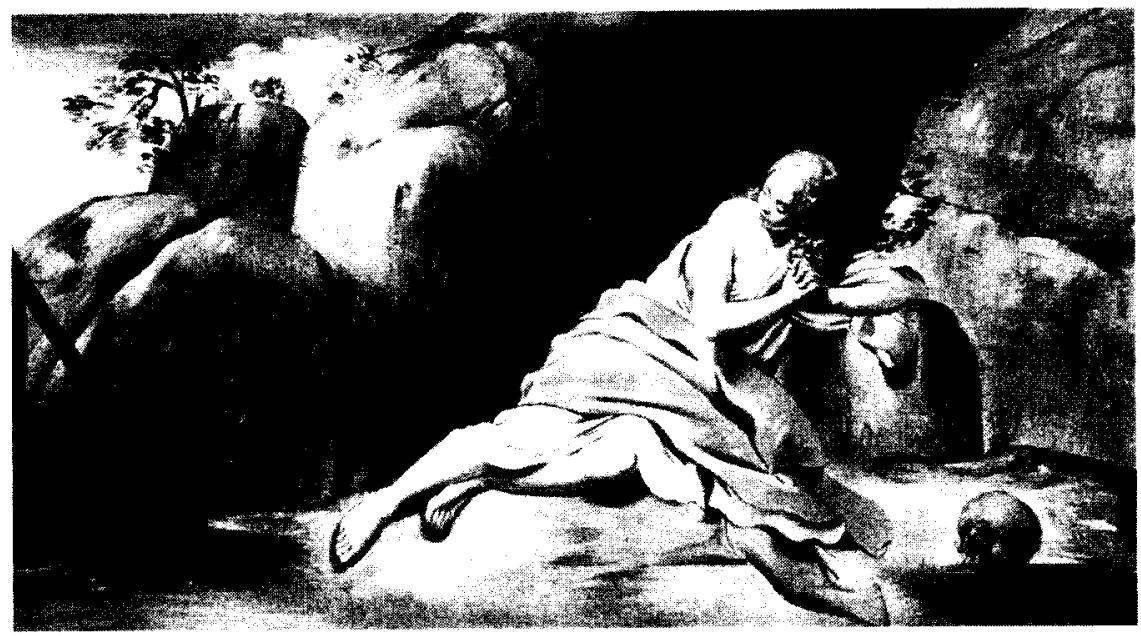

Fig. 5. Juan Bautista Maino: "Magdalena arrepentida" (Detalle). Madrid, Museo del Prado.

Durante el siglo XVII desaparecen los tipos derivados de la tradiciónı hispanoflamenca que en general no hacían sino restar expresividad a la escena del arrepentimiento, y los artistas buscan sobre todo una mayor concentración expresiva. Son magdalenas que difunden con sus rostros y sus actitudes sensación de dolor y arrepentimiento; y a ello contribuye en numerosas ocasiones su propia desnudez. Un magnífico ejemplo es la que protagoniza una tabla del retablo de las Cuatro Pascuas de Juan Bautista Maíno (Museo del Prado), de 1612, donde aparece la santa recostada junto a una roca, con el hombro y el brazo derecho descubiertos, unos magníficos cabellos rubios, y mostrando dos partes de tanta significación erótica en el siglo XVII como las pantorrillas y los pies ${ }^{40}$.

A mediados de siglo se fue precisando la iconografía de la Magdalena, que en la escuela madrileña quedó bastante codificada. Pereda, Antolínez o Carreño, por citar unos pocos ejemplos, difunden la imagen de una mujer sentada, aislada, rodeada de los símbolos de arrepentimiento y meditación, como el cilicio, la calavera, el crucifijo o los libros piadosos, y con unas actitudes que fluctúan entre la meditación, la contemplación y el dolor. Aunque siempre se representa joven, su expresión es más madura que en las magdalenas góticas y renacentistas. En cuanto a su desnudez, afecta sobre todo a los pies y al torso, que en ocasiones cubre ligera-

\footnotetext{
4i Juan Miguel Serrera: "Juan Bautista Maino: Retablo de las Cuatro Pascuas". Boletín del Museo del Prado, t. X (1989), págs. 35-41.
} 
mente con unos cabellos que invariablemente son largos y hermosos. También puede ocurrir que cubra casi todo su cuerpo, como alguna de Antolínez.

En cualquier caso, lo que parece absolutamente claro es que en la representación de la Magdalena se admitian desnudeces que hubieran sido censuradas en el caso de tratarse de una Venus o cualquier otra diosa pagana. Incluso a veces se pinta completamente desnuda, como en el inquietante lienzo atribuido a Loarte que guarda la Casa de Lope de Vega y cuya protagonista por único vestido posee una espléndida cabellera con la que resguarda las partes más intimas de su cuerpo ${ }^{41}$. Pero probablemente la imagen de la Magdalena hecha por un artista español de la época que a los ojos actuales puede tener mayor ambigüedad es una estampa dibujada y grabada en Roma por el valenciano Vicente Victoria que la representa recostada, semidesnuda y en pleno éxtasis. Esta turbadora imagen parece descendiente directa de Bernini, y en ella se mezcla el abandono extático de su Santa Teresa o su Beata Albertoni con las licencias a la hora de tratar la anatomía femenina que siempre se han permitido los artistas cuando representan a Magdalena ${ }^{42}$.

Vicente Victoria fue sacerdote, al igual que Juan Bautista Maíno; y muchas de las imágenes de las que hemos tratado fueron pintadas para ser colocadas en lugares de culto público. Sin embargo, no faltaron voces que se alzaron contra el excesivo desenfado en la representación de las penitentes. Melchor de Huélamo, por ejemplo, en su Libro primero de la vida y milagros, del glorioso confessor Sant Ginés de la Xara. Y de algunas cosas notables que ay en el monasterio, consagrado y dedicado a su santo nombre, sito en el reyno de Murcia, publicado en 1607 , afirma que habia visto "en casa de algunos pasteleros y bodegoneros, junto a la mesa, una Magdalena recostada, de las pinturas de León de Francia, que de ninguna manera se devía consentir» ${ }^{43}$; y el padre Interián aconseja cubrir a las penitentes con sacos, túnicas u hojas de palma, para así evitar representaciones de «Pelagias, Marias Egipciacas, Magdalenas, y otras mugeres anacoretas, gran parte desnudas, o a lo menos vestidas con poca decencia, cuyas imágenes, sin embargo de que se nos proponen estando en el desierto, y haciendo pentencia en él, excitan muchas veces tales movimientos, y afectos en los que las miran, que causan gran daño

\footnotetext{
4 Catálogo de la exposición Pintores del reinado de Felipe III, Madrid, 1993, $n^{\circ} 39$.

4. La estampa se produce en JuAN CARRETE: El grabado (La estampa como medio de comunicación). Madrid, 1984, pág. 215.

Murcia, Agustin Martinez, 1607, fol. $113 \mathrm{r}-\mathrm{v}$.
} 


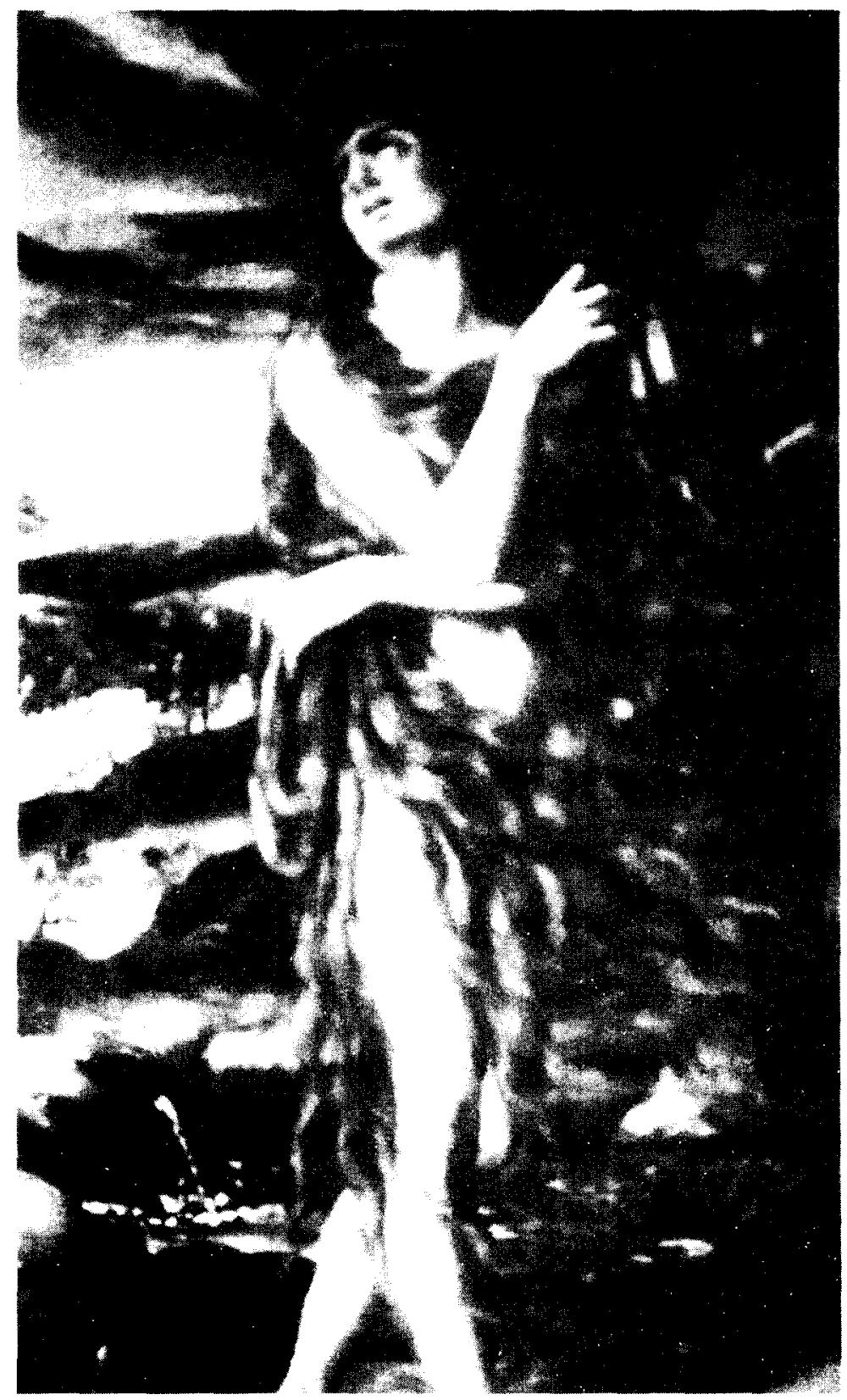

Fig. 6. Alejandro de Loarte: "Magdalena arrepentida". Madrid, Casa de Lope de Vega. 


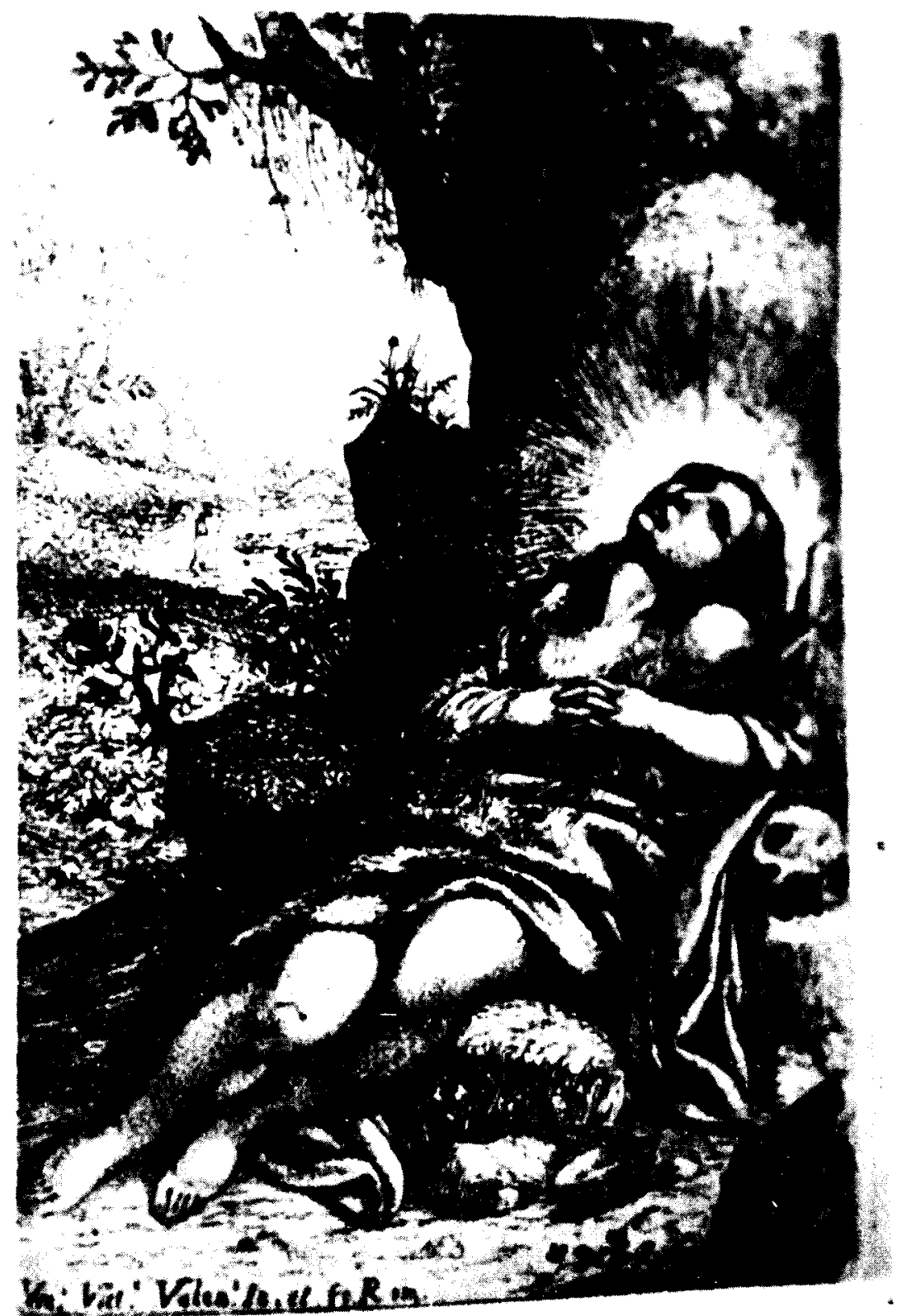

Fig. 7. Vicente Victoria: "Éxtasis de la Magdalena”. Cobre, talla dulce. 
en el alma, si no se borran después con lágrimas, y suspiros» ${ }^{44}$. Son, como decimos, posturas excepcionales frente a una opinión mayoritaria muy receptiva hacia la iconografía traicional de la santa; y que se compendia en un poema del siglo XVII dedicado «A una copia de la Magdalena que sacó el Pe. Gogenaga, de un orijinal de Guido, que tiene el medio cuerpo desnudo", cuyos últimos versos dicen así:

"Desnuda te retrató / sin faltar a la decencia, / porque dio más excelencia / al Alma, que en ti pintó. / Luego aunque te desnudó, / darte más decencia pudo, / si tu espiritu, aunque mudo, / más suspende, y pone en calma, / pues cuando arrebata el Alma / no divierte lo desnudo. // En fin desnuda te quiso / pintar el orijinal, / y asi fue el copiarte tal, / retrato, y de el Parayso, / conque es constante y preciso, / que el desnudar tu presencia / en ti fue mayor decencia; / pues te redujo el ferbor, / el sentimiento, y dolor, / a estado de la Ynoçencia" ${ }^{45}$.

Es muy curiosa la referencia al «estado de la Ynoçencia», pues trae a la memoria un lienzo de Antonio Arias conservado en Monforte de Lemos. En su parte izquierda aparece una mujer joven, desnuda de cintura para arriba, con los cabellos largos y sueltos y con los brazos cruzados sobre el pecho. No es, como podría pensarse, María Magdalena que ha subido al cielo, sino que se trata de una bienaventurada en estado de inocencia, que asiste al Juicio Final, que es el tema que narra el cuadro ${ }^{46}$. Los mismos elementos que en otros contextos podian hacer censurable una obra por su erotismo, en el caso de las magdalenas o las almas bienventuradas adquieren un significado completamente opuesto. Esto explica por qué consciente o inconscientemente a veces se ha relacionado la santa con figuras de la mitología clásica. En 1637, por ejemplo, un funcionario confundió una Magdalena penitente destinada a una ermita del Buen Retiro con una representación de Baco ${ }^{47}$, y en la Presentación de la Copia de los pareceres se alude a la posibilidad de transformar una Venus lasciva en una santa María Magdalena ${ }^{4}$, algo que se hizo de alguna forma efectivo en la Magdalena penitente de Tiziano (Museo Pitti), a la que se cree derivada de una Venus antigua ${ }^{49}$. Ya

${ }^{44}$ INTERIÁN: El pintor... t. I, pág. 39

4., Se incluyen en I. FaXARdo: Parnaso español. T. I, Biblioteca Nacional de Madrid, Mss, 3912, fol. 159-r-v-

4. Diego Angulo y Alfonso E. Pérez Sánchez: Historia de la pintura madrileña. Segundo terclo del siglo XVII. Madrid, 1983, pág. 29, lám 30.

"i José Maria AzCARATE: "Anales de la construcción del Buen Retiro". Anales del Instituto de Estudios Madrileños, t. I (1966), pág. 119.

44. Copia de los pareceres..., pág. 244.

4: Francesco Valcanover: La obra pictórica completa de Tiziano. Barcelona, $1974 n^{\prime \prime}$ 161. La relacion entre Venus y Magdalena también la establece Juan de Valdés en su Dialogo de las cosas ocurridas en Roma. 


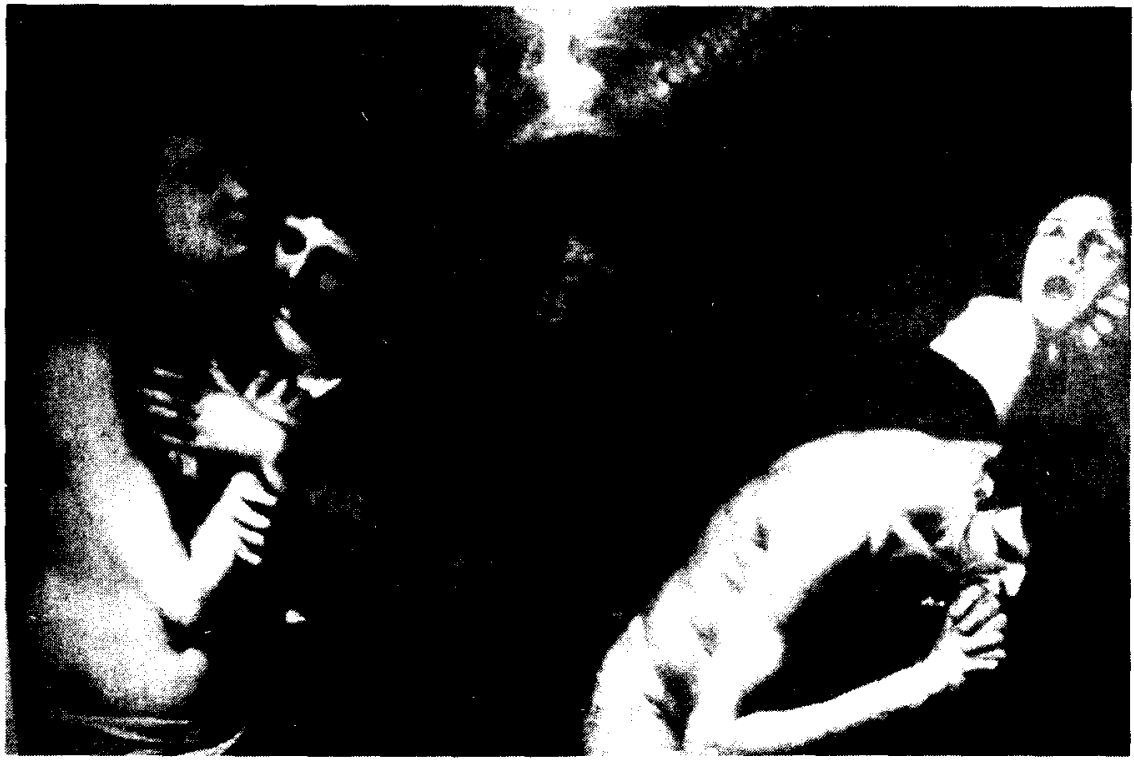

Fig. 8. Antonio Arias: "Juicio Final" (Detalle). Menforte de Lemos, Colegio del Cardenal.

en el siglo XVIII nos cuenta Nicolás Arce en sus Conversaciones sobre la escultura que al observar un caballero el desasosiego que producía en un criado suyo una imagen de Venus, la mandó transformar en una "penitente Magdalena» ${ }^{50}$. En estos casos se utiliza a Venus como figura con significación opuesta a la de nuestra santa; pero en alguna ocasión se ha utilizado la comparación con personajes de la mitología que también aparecen desnudas y tienen una significación positiva. Es el caso de Andrómeda, cuya historia fue interpretada en varias ocasiones en el siglo XVII en clave cristiana y que proporcionó el arquetipo visual para unos versos de Urbano VIII traducidos por Gabriel del Corral en los que Magdalena aparece junto a una roca, amenazada por un dragón del que la rescata el mismo Cristo ${ }^{51}$.

50 Madrid, 1786, pág. 113. Véase Javief Portus: «Los poemas de Bances Candamo dedicados a la "Magdalena" de Pedro de Mena". Actas del congreso Pedro de Mena y su época, Málaga, 1990, pág. 594. Otro ejemplo de confusión entre una figura perteneciente a la iconografia cristiana y un personaje del panteón grecolatıno nos lo ofrece un inventario de 1751 de la colección arqueológica de los duques de Medinaceli, donde de una ninta en actitud púdica se dice que "parece Susana o Venus". Véase VICENTE LLEO CANAL: “El jardín arqueológico del primer Duque de Alcalá". Fragmentos, $\mathrm{n}^{\circ} 11$ (1987), pág. 28.

"Véase JaVier PORTUS: "Difusión y transformaciones de un tema clásico en el Siglo de Oro: la liberación de Andrómeda". Cuadernos de Arte e lconografía, t. II, n 4 (1989), pág. 91. 
No conocemos censuras a Magdalenas concretas durante el siglo XVII, pero sí desde principios del XIX, lo que es muy significativo del cambio de mentalidad que se produjo en España a lo largo del XVIII. Así, en 1807 se recogió al comerciante Juan Caillard, establecido en la calle de Alcalá una Magdalena perteneciente a la serie Cours historique et élémentaire de Peinture ou Galerie complète du Musée Napoleon que traía de París por encargo de los marqueses de Aguilar y Camarasa y de la duquesa de Osuna y su hija, que se prohibieron por "deshonestas y lascivas" ${ }^{52}$; y según el inventario de los bienes dejados por Fernando vII a su muerte en 1834 figuraba en la llamada "Sala Reservada" del Museo del Prado, entre Venus, Dánaes, Dianas y ninfas, una Magdalena desmayada en brazos de dos ángeles llorosos, atribuida entonces a Aníbal Carracci ${ }^{53}$.

Para entender por qué en la Magdalena se admitían elementos que en otros contextos hubieran sido vedados hay que remitirse a la teoría del decoro, que fue el concepto vertebrador de todo el pensamiento sobre arte en la Europa contrarreformista y en esencia significaba la necesidad de la máxima correspondencia entre significante y significado ${ }^{54}$. Pero esta teoría implicaba además una forma de ver las obras de arte distinta a como ahora las contemplamos. En el Siglo de Oro una pintura era un conjunto de elementos narrativos dispuestos sobre un lienzo, que el espectador utilizando su inteligencia, su experiencia y su cultura tenia que «leer» e interpretar. Pero estos elementos narrativos no sólo eran los objetos con valor simbólico o los gestos de los personajes, sino también elementos puramente plásticos, como son las relaciones entre formas y colores. El español contemporáneo a El Greco, Maíno, Antolínez o el padre Victoria en una Magdalena antes que la representación de un desnudo veía una mujer que con su aislamiento, su expresión condolida, sus brazos cruzados, sus atributos de disciplina, su biografia -que nadie ignoraba- y su propia desnudez se convertía en la viva imagen del arrepentimiento y la penitencia; mientras que Venus, que no necesariamente tenía por qué aparecer más desnuda, era, por la propia significación de sus actos, símbolo de lujuria. Lo que se veía en un cuadro no era sólo una figura concreta, sino también, y sobre todo, una "historia» compendiada en una acción determinada. El ya citado José de Jesús María advertía del peligro de las pinturas mitológicas porque "están representando deshonestidad y las-

CARRETE: "El grabado y la estampa...”, pág. 435.

Archivo General de Palacio, 4808 , fol. 420r. Sobre la Sala Reservada y sus precedentes véase ARtuRo Colorado CaStellapy: "Desnudo, fuego y prohibición en la corte de los Borbones". Historia 16, t. XiX, n²24 (1994), págs. 88-105.

:4 Sobre este tema véase Palma Martinez-Burgos: Idolos..., págs. 209 y ss. 
civia, assi con su desnudez, como con la significación de sus historias" 55 . La Magdalena, con su belleza y desnudez nos recuerda un pasado que le había conducido a su estado actual, pero probablemente en la contemplación de su imagen tenía más peso la visión de los elementos de dolor y arrepentimiento, y cualquiera que viera hace unos siglos estas pinturas estaría probablemente de acuerdo con los versos del poema antes transcrito que aseguran que «cuando arrebata el Alma / no divierte lo desnudo».

Pero para intentar acercarnos a los modos de ver una Magdalena que existian en el siglo xvII hemos de tener en cuenta algunos aspectos más. Nos podemos preguntar, por ejemplo, por qué precisamente la expresión arrepentida y penitente de la santa no se consideraba un elemento más de entre los que configuraban su atractivo erótico, como podría considerarse hoy en dia ${ }^{56}$. La respuesta probablemente se encuentre en los cambios que se han producido desde entonces en lo que se refiere a los campos que abarca la sexualidad y al papel de la mujer. En el siglo XIX, como una faceta más del desarrollo de una moral y un sentimentalismo burgueses, se extendió el ideal de una mujer cuyas pasiones debían limitarse a su casa y sus hijos, pues, imperfecta por naturaleza, podía convertirse en el más importante agente de ruina moral, económica o sanitaria de una sociedad. El tema trajo como consecuencia la creación de una ingente cantidad de obras artísticas y literarias en las que se definía a la mujer como un ser susceptible de encarnar la misma maldad y en general se proyectaban juicios de valor negativos sobre aquellas que no querían o podían ajustarse al papel que les reservaba la sociedad ${ }^{57}$. Pero el observador o el lector actual de tantos cuadros y novelas tiene la sensación de que existía una auténtica atracción masculina por el tema, que está probablemente en el origen del atractivo sexual que hoy puede tener la imagen no sólo de Circes, Salomés, sirenas o todo lo que puede englobarse en el título de «mujer fatal», sino también de esclavas, penitentes y sufrientes en general. Desde hace dos siglos se han extendido las formas de lo considerado dentro de los dominios de la sexualidad; y uno de los campos en los que

Jose de Jesús MaAia: Segunda parte...

Hoy mismo son frecuentes interpretaciones descontextualizadas de las imágenes antiguas de la Magdalena y otros santos, de las que, con mentalidad contemporánea, suele considerarse que cuando se pintaron fueron vehículos de significado erótico. Véase, entre muchos otros ejemplos, P. Garcia Gutierrez y A. Martinez Cafbajo: "Iconografia de San Sebastián y la Magdalena. Plenitud de la belleza masculina y femenina". Antiquaria, $n^{\circ} 103$ (1993), págs. 50-55.

Véase ERIKa Bornay: Las hijas de Lilith. Madrid, 1990, y, sobre todo, Bram DiJkstra: Idolos de perversidad. La imagen de la mujer en la cultura del fin de siglo. Madrid, Debate, 1994. Quiero agradecer desde aqui a Sagrario Aznar su gentileza a la hora de proporcionarme información sobre estos temas. 
ha ocurrido esto es el que se refiere a la relación entre dolor y placer erótico, de lo que desde el punto de vista artístico es prueba el gran éxito que desde la segunda mitad del siglo pasado tuvo la pintura de esclavas.

En el Siglo de Oro las relaciones entre los sexos se basaban en la asunción general del dominio masculino, y en ese contexto no era concebible la tipificación de un comportamiento de carácter sadomasoquista. La relación entre dolor y placer no se enmarcaba en el ámbito de lo sexual, sino que pertenecía al dominio de la religión. Ninguna relación de sucesos de esa época, que tan amigas eran de narrar "delitos" de carácter sexual, y ningún libro de confesión o tratado de moral abordan el tema del masoquismo; $y$, por el contrario, son innumerables las guías espirituales en las que se recomienda la utilización de cilicios y castigos corporales personales para la purificación del espíritu. Raro es el español de esos siglos que no usó alguna vez en su vida el castigo corporal para sí mismo. Lope de Vega, por ejemplo, la noche anterior a su muerte había teñido de sangre las paredes de su celda como consecuencia de su flagelación. Pero además, al leer las biografías de frailes, sacerdotes o monjas no sólo se advierte que era una práctica generalizada y prácticamente obligatoria para el clero, sino que son numerosos los casos en los que es posible hallar una obsesión morbosa por este tipo de actos, en los que algunos encontraban auténtico $e$ indefinible placer. A la beata Mariana de Jesús, por ejemplo, como manchaba las paredes de sangre, sus padres le prohibieron seguir flagelándose, por lo que pasaba a casa de una vecina a hacerlo a escondidas. Su cama era a veces una cruz y en ocasiones zarzas y espinas; los escapularios que utilizaba eran de hojalata con pinchos; una de sus bebidas habituales la hiel y el vinagre; en el calzado no faltaban las piedras, y «para las disciplinas sangrientas usaba de instrumentos de alambre retorcido, y pedazos de hierro de un palmo de largo, poco menos gruesos que un dedo". Suyos son unos versos bastante torpes, pero muy expresivos:

\author{
"Que la Cruz abrazada \\ no es la más pesada. \\ Y la mortificacion \\ alivia la aflicción.»
}

Su biógrafo Juan de la Presentación, que utiliza una autobiografía, asegura: "Siempre quisiera estar padeciendo, por parecerla no vivía quando padecía: y así como el dolor, y debilidad de las manos impedía el rigor de las disciplinas, le compensaba con tiernas lágrimas» ${ }^{58}$.

im Juan de la Presentacion: Vida devola de la beata madre Maria Ana de Jesus. $3^{\circ}$ ed., Madrid, Isıdoro Hernandez, 1784, pags. 98-105. La primera edición es de mediados del siglo xvII. 
Ejemplos similares pueden encontrarse a docenas, tanto en biografías como en autobiografías, en las que invariablemente se citan para ponderar las cualidades del personaje. Incluso a lo largo del siglo XVII se fue extendiendo la costumbre de incorporar objetos alusivos a la penitencia y la mortificación en los retratos de los religiosos que se habían señalado en este campo. Simón de Rojas, que dormía crucificado en una cruz de madera, aparece en la estampa que ilustra su biografia portando otra cruz, coronado de espinas, con una soga en el cuello, y con cilicios esparcidos por el suelo ${ }^{59}$; y en la que aparece al principio de la vida de Leonarda del Santísimo Sacramento se la representa de medio cuerpo y coronada de espinas. Dirige su mirada a un crucifijo que sostiene con la mano derecha, y la izquierda la tiene apoyada sobre una calavera que está sobre una mesa sobre la que también aparecen un cilicio y una cruz con pinchos para mortificarse ${ }^{60}$. La afición al retiro y la penitencia le venía de niña, cuando planeó con su hermana retirarse al campo, para lo cual hicieron "una buena provisión de cilicios, disciplinas, rosarios, cruzes, reloxes y calaveras de madera (que de otras no podíamos entonces aver)" ${ }^{6 !}$.

La sociedad española admiraba la mortificación, y la alentaba por su utilidad para estimular el sentimiento religioso. No creemos que la mayoría de la gente contemplara en ella la posibilidad de convertirla en un método de transgresión sexual. Por eso, el atractivo erótico que para un contemporáneo puede tener la penitencia de una santa o un santo, para el español del Siglo de Oro era uno de los miuchos elementos del cuadro que le invitaban a hacer una reflexión de carácter religioso. Los miembros desnudos de María Magdalena son, aunque no lo parezcan, carne macerada y mortificada, como declaran los cilicios que tiene ante sí; y su figura no sólo representaba la esperanza de recibir perdón por cualquiera de nuestros pecados sino que es también un aviso de las desastradas consecuencias que puede tener el mal uso de la belleza personal y un ejemplo de cómo a través de la penitencia y la mortificación purificamos nuestro espíritu.

El estudio de la iconografía de la Magdalena penitente no es el único camino para probar que para la calificación de una pintura como desho-

Immagine..., $\mathrm{n}^{\circ} 86$

wh LUIS DE BLANES: Resumpta breve de la penitente, y virtuosa vida de la ven. madre Leonarda del Santissimo Sacramento. Dicha en el siglo Leonarda Rison, carmelita descalça, en el convento de S. Joseph de la ciudad de Valencia. Valencia, Francisco Mestre, 1679.

Idem, pág. 14 
nesta en el Siglo de Oro entraban en juego hábitos perceptivos y tradiciones culturales distintos a los que existen hoy en día. La mitología también nos lo prueba, aunque en este caso con un sentido diferente. A juzgar por las alusiones literarias, como las que nos proporciona el teatro de Lope de Vega ${ }^{62}$, la escena que se consideraba arquetípica de una situación amatoria irregular era la que tenía a Venus y Adonis por protagonistas, que fue también el episodio predilecto de pintores y coleccionistas ${ }^{63}$, y que mereció censuras continuas por parte de los que escribieron contra las pinturas deshonestas. Bernardino de Villegas llama a Adonis "el lascivo" y pone como ejemplo de pintura deshonesta la que narra su historia ${ }^{64}$, y en la Copia de los pareceres... Bernardino Rodriguez escribe:

"Cuáles sean pinturas lascivas dignas de condenarse tan gravemente declaran algunos autores exemplo Veneris, aut Adonis detectis pudendis, aut diaphano velo operatis: y de lo mismo será de otras como ella".

Los jesuitas, por su parte, dicen:

«De la gravedad del pecado en pintar semejantes figuras, como las de Venus, o Adonis desnudas, las de Tarquino, y Lucrecia en sus pretensiones, y acometimientos, y semejantes, tratan muchos y graves Doctores" ${ }^{65}$.

Pero en los cuadros que representan a Venus y Adonis la deshonestidad se establece al menos en tres niveles diferentes. En primer lugar, en el más inmediato de reconocimiento visual, que nos muestra a dos personajes más o menos desnudos. A continuación, por la significación de su historia, que la mayor parte del público al que se dirigía este tipo de obras conocía bien. $Y$ existe un tercer nivel, de gran efectividad, que afectaría a lo que podrían llamarse arquetipos visuales. En este caso se trata de la imagen de un hombre recostado en el regazo de una mujer ("Siéntase Venus, y pónese Adonis en su regazo, recostado", como dice una didascalia de la comedia de Lope dedicada a ambos personajes) ${ }^{66}$, que adquirió una naturaleza arquetípica y sirvió de inspiración a muchas otras escenas de carácter

\footnotetext{
"i. Véase Javier Portus: Lope de Vega y las artes plásticas. Madrid, 1992, especialmente págs. 275 y ss.

LOPEZ TORRIJOS: La mitología..., pàgs. 271 y ss.

i.4 Bernardino de VILLegas: La esposa..., págs. 436-437.

(.) Copia de los pareceres..., págs. 250 y 257. Sobre estos temas véase PIERRE CIVIL: "Erotismo y pintura mitológica en la España del Siglo de Oro". Edad de Oro, t. IX (1990), págs. 39-49.

(4i) Adonis y Venus. En Lope de Vega: Obras escogidas. Ed. F.C. SAINz DE ROBLES, $4^{\circ}$ ed., Madrid, 1964, págs. 560-562.
} 
erótico, como demuestra El hijo de la Iglesia, un auto sacramental de Lope de Vega donde se utiliza la escena protagonizada por Venus y Adonis para caracterizar nada menos que a la Lascivia. En ella una acotación escénica reza "Duérmase [el Hombre] en el regazo de la Lascivia"; y el Deleite, al ver la escena dice: "De negro sueño ven, / en tus brazos se ha dormido" ${ }^{6}$.

Esta postura está también en el origen de un cuadro de Murillo en apariencia "costumbrista", la Anciana despiojando a un niño (Munich, Pinacoteca Antigua), que en realidad, como demostró Brown, encierra claras alusiones eróticas ${ }^{68}$.

Una divertida prueba de que el episodio del que hablamos se consideraba la imagen amatoria por excelencia nos la ofrece Lope en Más pueden celos que amor, donde Octavia se sirve irónicamente de él para expresar la distancia física que mediaba entre ella y un galán cuando éste fue a hacerle una visita en la que no hicieron más que conversar:

Mas quiero también que adviertas / que mesurado en la silla, / yo en la almohada compuesta, / él era Adonis pintado, / y yo era Venus de piedra ${ }^{63}$

En contra de sus deseos, la cita habia sido absolutamente casta, y no encontró mejor manera de expresar su desilusión que describirla como un negativo del episodio de Venus y Adonis: uno pintado y otro de piedra, es decir, inmóviles; y él sentado en la silla, y ella "compuesta" en el estrado, todo lo contrario a la imagen del hombre en el regazo de la mujer.

Este tipo de escenas, que podian ser interpretadas por otros personajes mitológicos, siguieron conservando su poder en el siglo xvili; y de ello es indicio el hecho de que la única pintura española que se confiscó por indecente a Sebastián Martinez, el amigo de Goya en Cádiz, fue un Sansón y Dalila de Alonso Cano en el que el forzudo aparecía durmiendo en el regazo de su peluquera ${ }^{70}$

A los ojos actuales puede llamar la atención el gran significado erótico que adquirió entonces la imagen de la que hablamos, entre otras cosas porque su significado actual no es tan explícitamente sexual, sino que tiene más que ver con la idea de una manifestación de ternura o de ero-

Obras de Lope de Vega. Madrid. 1963-1972, t. XVI, pág. 109

JONATHAN BROWN: "Murilio, pintor de remas eróticos. Una taceta inadvertida de su obra", GOYA, n' 169-171 (1982-1983), pag. 38.

Comedras escogrdas de Lope de Vega. Madrid, 1946-1952, t. Il, pag. 175.

Jose MANUEl Cruz VALDOvinos: "Inquisidores e ilustrados: las pinturas y estampas inde. centes de Sebastián Martinez". IV Jornadas de Arte: el ante en tiempo de Carios il. Madrid, 1989, pág. 316. 
tismo adolescente. Pero lo más curioso de esta escena es su gran parecido con la que representa el que puede considerarse ejemplo cumbre para la tradición cristiana del amor sublimado. Nos referimos a la Piedad, en la que la Virgen acoge en su regazo el cuerpo sin vida de su Hijo. No estamos en situación de dar una explicación a estas similitudes; pero nos gustaría señalar que el mecanismo mental que puede convertir, según el contexto, un arquetipo visual de amor y dolor maternos en un arquetipo de erotismo es precisamente el mismo que puede hacer de una Magdalena hermosa y semidesnuda la imagen misma del arrepentimiento y la contricción.

Con estas no se acaban, ni mucho menos, las reflexiones a que puede dar lugar el estudio de la indecencia en pintura en el Siglo de Oro. Pierre Civil, por ejemplo, ha profundizado en el estudio de la relación entre erotismo y pintura mitológica en España, y a Carlo Ginzburg debemos agudos comentarios sobre la relación entre el sentido de la vista y el erotismo ${ }^{71}$. Otro campo, por ejemplo, que puede aportar datos de interés para el tema es el que se refiere a los vestidos y sus colores; pues no hay que olvidar que hasta no hace mucho en amplias zonas españolas se distinguia entre colores "honestos» $y$ "no honestos».

En lo que se refiere a la España del Siglo de Oro el tema de la pintura deshonesta puede ponerse en relación con el de la calidad artística y con la polémica sobre el dibujo y el color. De lo primero nos han quedado varios ejemplos significativos. El ya citado Francisco Arias implicitamente relaciona las "cosas lindas, hermosas, y de muy gracioso y agradable parecer" con las "figuras de mugeres, o de hombres deshonestamente pintadas" 72; José de Jesús María dice que los dueños de este tipo de obras las tienen por adorno "más alegre y agradable" que cualquier otro ${ }^{73}$; Luisa María de Padilla afirma que quienes las poseen ponen como excusa el «adornar las casas de primorosas obras en el arte» ${ }^{74}$; el caballero protagonista de la historia de José de Jesús Maria también apelaba a la gran calidad artística de su Leda; Arcos, en su vida de Simón de Rojas, nos asegura que «florecían en Europa primorosos artifices en la pintura, y por mostrar la valentía con que imitavan con el pincel la naturaleza la pintavan desnuda" ${ }^{75}$; y un

\footnotetext{
Pierre Civil., "Erotismo..."; Carlo Ginzburg: "Tiziano, Ovidio e i codici della figurazione erotica nel 500". En Tiziano e Venezia, Venecia, 1980, págs. 125-135.

Segunda parte..., pág. 402.

Primera parte..., pág. 798.

Excelencias..., pág. 602.

Primera parte... Simon de Roxas, pág. 297
} 
personaje de la comedia de Lope La prueba de los amigos excusa sus alabanzas a una Lucrecia y un Adonis diciendo que no se dirigen a lo que representan sino a la "buena mano" que las pintó ${ }^{76}$. Pero es fray Juan de Santo Tomás, uno de los firmantes de la Copia de los pareceres, quien pone el dedo en la llaga cuando escribe: "Y no sólo no se escusa el tenerlas por causa de la excelencia, y el arte de la pintura, sino que esto mismo es lo que más lo suele agravar, y ser causa de mayor daño, y ruyna" ".

Para los hombres cultos del Siglo de Oro existía una relación directa entre la calidad estética de una obra y su eficacia persuasiva. Por ello, en el caso de los cuadros deshonestos se creía que su mayor calidad iría unida a una más intensa y eficaz incitación a la lujuria. Fray Diego de Tapia, por ejemplo, asegura que «quanto mayor fuere el primor del arte, tanto más eficaz será la ocasión y peligro" ${ }^{88}$; y Pacheco, para ponderar el desasosiego que puede producir una figura deshonesta bien pintada, nos cuenta la historia de un agustino que "estando a la mitad de la Misa levantó los ojos (hacia un "Juicio Final» de Martín de Vos) y vio una figura frontera de muger, con harta belleza, pero más descompuesta, y fue tanta la fuerza que hizo a su imaginación, que se vio a punto de perderse" ${ }^{79}$.

En la España del momento para aludir a pinturas caracterizadas a la vez por lo lascivo de su tema y por su alta calidad artística se utilizaban dos nombres: Tiziano y Miguel Angel. Esto daba ocasión para insistir en el poder persuasivo de sus cuadros. Así, el poderoso protagonista de la comedia de Lope La quinta de Florencia engalana su casa con pinturas de ambos, cuyo poder seductor es tan alto que provoca en él una pasión violenta que le llevará a una violación. Valerio, un personaje de La viuda valenciana, se disfraza de estampero para lograr sus fines amorosos, y entre las piezas que vende a su amada Leonarda figura "el Adonis de Tiziano, / que tuvo divina mano / y peregrino pincel». En el auto El yugo de Cristo, en el que pudo intervenir Lope, aparece la Idolatría tratando de vender al hombre estampas que representan la Riqueza, la Hermosura, la Venganza, el Juego, la Avaricia, la Codicia y la Gula, lo que hace que su cliente se debata entre los consejos contrapuestos que las personificaciones de la Razón y el Apetito le brindan; y para atraérselo el tentador estampero alude no sólo a la iconografía de sus estampas, sino también a la aita calidad de sus supuestos autores: Fidias, Lisipo, Praxiteles y Apeles.

Citamos por Miguel Morán: "Aqui fue Troya...", pág. 171.

Copia de los pareceres..., pág. 252.

Idem, pág. 255.

Francisco Pacheco: Arte de la pintura. Ed. F.J. Sanchez Cantón, 1956, t. I, pág. 307. 
En un sector cualitativamente importante de la sociedad española el rechazo hacia las pinturas no se dirigía exclusivamente a aquellas de temas que se consideraban "peligrosos" para la integridad moral de los espectadores, sino que iba destinado a todo lo que los cuadros pudieran tener de goce sensual. Uno de los que pensaban así era Francisco de Villava, quien en sus Empresas espirituales y morales escribe agriamente:

"póngase en tu persona todos los bienes, que los ricos an posseydo, dete la fortuna más dinero que suele dar a los particulares (...) levántense en tu honor estatuas, goza de pinturas, y de todo lo que el excesivo propio amor a trabaxado, no aprenderás de todas estas cosas sino cudicias vanas" ${ }^{80}$.

En este contexto creemos que es posible estudiar, como ya hiciera Darst ${ }^{81}$, la polémica dibujo-color, que fue fundamental en la teoria y la práctica artísticas españolas del Siglo de Oro, en relación con los juicios sobre la pintura mitológica. Frente al dibujo, que era el instrumento de la Idea y expresaba contenidos racionales, el color era la parte sensible de la pintura y a la que le estaba reservado el campo de las emociones. Cárdenas al tratar sobre el hombre desnudo que se le apareció a Damiana de las Llagas, nos dice que Dios, en su papel de pintor, "como tiempla los colores, y lineas de la pintura, tiempla también los afectos de quien la mira" " ${ }^{32}$, con lo que el escritor establece una relación directa entre color y eficacia persuasiva. En España se extendió entre ciertos medios un fuerte prejuicio contra el poder seductor del arte; y no había cuadros a ojos de los contemporáneos tan "perturbadores" como algunos de los venecianos que guardaban las colecciones reales, en especial los que salieron del pincel de Tiziano; de manera que, no fueron raras las condenas implícitas de la pintura colorista por su naturaleza potencialmente peligrosa.

\footnotetext{
Francisco de Villava: Empresas espirituales y morales. Baeza, 1613, fol. 27r. 22 y ss.

D. H. DARST: Imitatio. Polémica sobre la imitación en el Siglo de Oro. Madrid, 1985, págs.

CaRdenAs: Historia ... Damiana de las Llagas, págs. 432-433.
} 